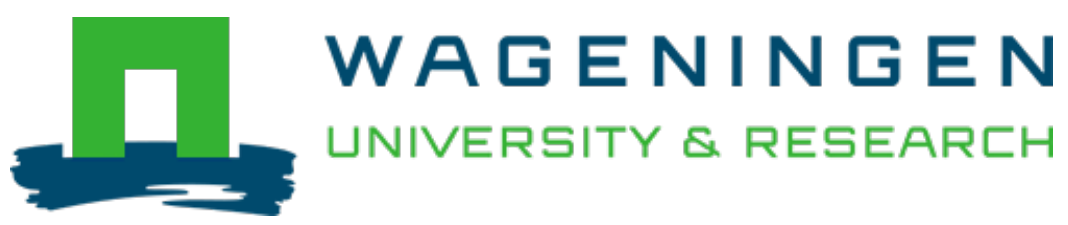

\title{
Revealing the nutrient limitation and cycling for microbes under forest management practices in the Loess Plateau - Ecological stoichiometry
}

\section{Geoderma}

Zhang, Jiaoyang; Yang, Xiaomei; Song, Yahui; Liu, Hongfei; Wang, Guoliang et al

https://doi.org/10.1016/j.geoderma.2019.114108

This article is made publicly available in the institutional repository of Wageningen University and Research, under the terms of article $25 \mathrm{fa}$ of the Dutch Copyright Act, also known as the Amendment Taverne. This has been done with explicit consent by the author.

Article 25 fa states that the author of a short scientific work funded either wholly or partially by Dutch public funds is entitled to make that work publicly available for no consideration following a reasonable period of time after the work was first published, provided that clear reference is made to the source of the first publication of the work.

This publication is distributed under The Association of Universities in the Netherlands (VSNU) 'Article $25 \mathrm{fa}$ implementation' project. In this project research outputs of researchers employed by Dutch Universities that comply with the legal requirements of Article $25 \mathrm{fa}$ of the Dutch Copyright Act are distributed online and free of cost or other barriers in institutional repositories. Research outputs are distributed six months after their first online publication in the original published version and with proper attribution to the source of the original publication.

You are permitted to download and use the publication for personal purposes. All rights remain with the author(s) and / or copyright owner(s) of this work. Any use of the publication or parts of it other than authorised under article $25 \mathrm{fa}$ of the Dutch Copyright act is prohibited. Wageningen University \& Research and the author(s) of this publication shall not be held responsible or liable for any damages resulting from your (re)use of this publication.

For questions regarding the public availability of this article please contact openscience.library@,wur.nl 


\section{Revealing the nutrient limitation and cycling for microbes under forest management practices in the Loess Plateau - Ecological stoichiometry}

\section{A R T I C L E I N F O}

Handling Editor: Ingrid Kögel-Knabner

Keywords:

Forest management practices

Ecological environment

Ecological stoichiometry

Threshold elemental ratio

Stoichiometric homeostasis

\begin{abstract}
A B S T R A C T
Forest management practices are commonly used in plantation forestry to obtain renewable energy and harvest biomass, in addition to maintaining the ecological environment, by changing the flow of carbon (C) and nutrients in the food webs of terrestrial ecosystems. To identify which forest management practices, alleviate soil nutrient limitation and impact stoichiometric homeostasis in relation to microbes, we used a Pinus tabuliformis plantation in the Loess Plateau where forest management practices were conducted since 1999. Five forest management practices were implemented: two at the forest level ( $P$. tabuliformis with and without ground litter, CK, LRL) and three of different vegetation restorations after clear-cutting ( $P$. tabuliformis seedlings (SPL), grass land (GL), and shrub land (SL)). Generally, the threshold elemental ratios for carbon:nitrogen (TER $\left.{ }_{\mathrm{C}: \mathrm{N}} ; 7.77\right)$ and carbon:phosphorus (TER $\mathrm{C:P}$; 44.37) were lower than the ratios influenced by forest management practices. The forest management practices significantly influenced ecoenzymatic activity and the ratios of ecoenzymes; however, the scale of the ecoenzyme activities for acquiring both organic $\mathrm{N}$ and organic $\mathrm{P}$ to that for acquiring $\mathrm{C}$ still follow the global pattern. The regression coefficients of C:N and C:P between the soil and microbial community at $0-20 \mathrm{~cm}$ and $20-40 \mathrm{~cm}$ depths were also influenced by these practices. Thus, the influence of forest management practices on the soil microbial community was limited by $\mathrm{N}$ and $\mathrm{P}$ in the Loess Plateau. The soil microbial community changed ecoenzymatic activities and ratios of ecoenzymes and even changed microbial community in order to balance elemental limitations in the soil. Finally, forest management practices have a minimal impact on the stoichiometric homeostasis of the microbial community at our study site.
\end{abstract}

\section{Introduction}

The Loess Plateau is a typical and ecologically fragile area in China, where forests and grasses once destroyed to expand the area of arable land to feed people eventually led serious vegetation destruction and soil erosion. To improve the ecological environment of this region, and to resolve local economic needs of timber, Pinus tabuliformis forests has become one of the largest artificial forest species grown on the Loess Plateau. Forests store $>70 \%$ of global soil organic carbon, representing a globally important C sink (Luyssaert et al., 2010; Goodale et al.,
2002). In addition, forests have significant roles in inducing global climate change by reducing or increasing atmospheric $\mathrm{CO}_{2}$ concentrations (Six et al., 2002; Jobbagy and Jackson, 2000). However, a previous study demonstrated that the soil beneath $P$. tabuliformis forests is relatively poor, especially the active $\mathrm{N}$ content (Zhang et al., 2019). Therefore, certain management practices are used in forest plantations, including the removal of litter and different types of restorations following clear-cutting. These practices not only facilitate the acquisition of renewable energy and biomass harvest, also might alleviate this limitation for the microbial community, thereby improving the

\footnotetext{
* Corresponding Author at: Xinong Rd. 26, Institute of Soil and Water conservation, Yangling, Shaanxi 712100, PR China.

E-mail addresses: jiaoyang9666@163.com (J. Zhang), xiaomei.yang@wur.nl (X. Yang), songyahh@163.com (Y. Song), liuhongfei@nwafu.edu.cn (H. Liu), glwang@nwsuaf.edu.cn (G. Wang), xuesha100@163.com (S. Xue), gbliu@ms.iswc.ac.cn (G. Liu), coen.ritsema@wur.nl (C.J. Ritsema), violette.geissen@wur.nl (V. Geissen).
} 
ecological environment.

These practices might influence different links of soil biogeochemical processes as a cycle, for example, soil microbes would adjust to the changed amount and ratios of carbon (C) and nutrients entering the soil, then the ability of decomposition changed because of the changed soil microbes would influence amount and ratios of carbon and nutrients entering soil in turn. The specifically influenced ways are as follow: First, changes to the mesoclimate driven by alterative $\mathrm{CO}_{2}$ concentrations might alter the amount and ratio of soil carbon (C) and nutrients (Sayer, 2006), temperature and soil moisture, which would impact plants and microbes in the biogeochemical process. Second, litter removal and different litter biomass from different types of vegetation might also influence carbon and nutrient content and ratios entering soil, which soil microbes would try to adjust to the new soil status. Furthermore, different types of vegetation have different nutrient requirements from the soil, as well as different root exudates, thus influencing nutrient cycling in the soil. Such changes to soil nutrients content and ratios might influence the soil limitation status for the soil microbial community and, hence, the status of the soil microbial community and soil nutrient cycling in soil biogeochemical cycles. Some studies have demonstrated that soil microbial properties, soil microbial biomass, composition and soil microbial activity, could be used as potential indicators to determine how forest managements practices impact the soil (Li et al., 2004; Sicardi et al., 2004). Therefore, many studies have investigated how forest management practices influence soil biogeochemical cycles, with a focus on the microbial community. For instance, Gao et al. (2014) showed that orchards and farmland soils have considerably higher $\mathrm{C}$ and $\mathrm{N}$ density and storage than forest soils. Acosta-Martinez et al. (2008) showed that soil microbial biomass $\mathrm{C}$ is higher in soils under trees and pasture compared to vegetable crops. Thus, different types of vegetation influence the structure of the microbial community to cope with different soil status (Bissett et al., 2011). Soil biogeochemical processes (e.g., microbial biomass, soil respiration) tend to be inhibited in forests subject to litter removal. However, Zhao et al. (2017) showed that litter removal minimally affected $\mathrm{C}$ and nutrient cycling, or microbial biomass and community structure, in a pine plantation, which has been supported by other studies (Huang and Spohn, 2015). However, these studies focused on the different steps of biochemical cycles influenced by forest management practices, with inconsistent results. Consequently, it is difficult to quantify soil nutrient condition and the nutrients cycle across biochemical cycles.

Ecological stoichiometry involving biogeochemical cycles could show the flow of soil energy and nutrients among trophic levels in food webs. According to it, resources could also be reallocated to the activity of ecoenzymes to mediate the imbalance between resources and soil microbial communities. First, soil ecoenzymes, as the mediators and catalysts of biochemical processes in soil, could be mediated by the relationship between soil nutrients and soil microbial communities. They could also function in nutrient mineralization and cycling, the decomposition and formation of soil organic matter (Acosta-Martinez et al., 2007). Thus, soil ecoenzyme activities are usually considered sensitive and important indicators that reflect the relationship of soil quality with soil health and soil microbial growth in response to forest management practices (Raiesi and Beheshti, 2015; Salazar et al., 2011). However, different practices produced inconsistent results regarding the activity and ratio of ecoenzymes (Li et al., 2014; Acosta-Martinez et al., 2008). Inconsistent results were also obtained with respect to litter-removal. Lie et al. (2016) showed significantly lower ecoenzyme activity in litter-removed plots compared to the control. In comparison, Veres et al. (2015) showed that polyphenol oxidase activity was not significantly influenced by litter-removal, while $\beta$-glucosidase activity was significantly decreased by removal of roots and litter and did not show significant difference between CK and no litter in early years. In addition, threshold elemental ratios (TERs) and stoichiometric homeostasis, which is the central concept of ecological stoichiometry, were integrated to establish which element limits the growth of the microbial community, and whether the soil microbial community adapted to new soil status maintains stoichiometric homeostasis. Generally, we used ecological stoichiometry to illustrate coping strategy of the microbial community from the ratios and content of soil resources limiting microbial growth, to the ratios and content of microbial communities, and how the microbial community adjusted to the imbalance between these ratios and whether the final stoichiometric homeostasis was affected.

Here, we investigated how forest management practices could alleviate soil nutrient limitation and change the ecological environment in aspect of microbes. We designed an experiment with litter removal, and different types of restoration after clear-cutting. We hypothesized that: (1) the elemental limitation status for soil microbial community growth would be influenced by different management practices, (2) elemental flow among trophic levels, enzymatic activity and ecoenzymatic stoichiometry would vary among different forest management practices to maintain a balance between resources and microorganisms, and (3) different restoration practices or litter removal would not impact the stoichiometric homeostasis of microbes. We hope use this experiment design to reveal which forest management practice is suitable in the Loess Plateau to improve the ecological environment.

\section{Material and methods}

\subsection{Site description}

The experiment was conducted at the Tielongwan plantation, on the eastern edge of Huanglong Mountain forest $\left(35^{\circ} 39^{\prime} \mathrm{N}, 110^{\circ} 06^{\prime} \mathrm{E}\right)$, Yichuan County, northern Shaanxi Province, China. The region is characterized by a continental climate, with a mean annual temperature of $9.7^{\circ} \mathrm{C}$. The average frost-free period is 180 days. Mean annual precipitation is $584.4 \mathrm{~mm}$, with approximately $60 \%$ occurring between July and September. The soil is a gray forest soil (Gray Luvisol, FAO soil classification). The landscape consists of rolling hills, with slopes from $20^{\circ}$ to $25^{\circ}$. The elevation of the plantation ranges from 860 to $1200 \mathrm{~m}$.

The artificial $P$. tabuliformis forest in our experiment covers an area of $600 \mathrm{ha}$, and was established in 1966. The zonal vegetation is temperate deciduous broad-leaved forest. The main trees are $P$. tabuliformis. Other vegetation includes Populus davidiana, shrubs (like Lespedeza bicolor Turez, Elaeagnus pungens Thunb, Rosa xanthina Lindl, Spiraea Salicifolia L., and Caragana korshinskii Kom), and herbs (like Carex lanceolate Boott.), which are sporadically distributed through the forest.

\subsection{Experimental design and soil sampling}

The experiment was conducted in an artificial $P$. tabuliformis forest that had a similar climate, location and terrain conditions, and forest age. In 1999, different forest management practices were implemented, including litter removal and restoration using different types of vegetation after clear-cutting. Five treatments were used; namely, artificial $P$. tabuliformis (CK), litter-removal land (LRL), seedlings of $P$. tabuliformis land (SPL), grass land (GL) and shrub land (SL). Three plots were sampled for each treatment, each of which was $5 \times 10 \mathrm{~m}^{2}$.

The soil was sampled during September 2015. Soil cores were collected from the $0-20$ and $20-40 \mathrm{~cm}$ layers at five randomly selected locations in each plot and were combined to form composite samples for each layer. All samples were sieved through a 2-mm mesh after stones and roots had been manually removed. The sieved samples were separated into three subsamples. One subsample was air-dried and then sieved through a $0.25-\mathrm{mm}$ mesh to determine SOC, total $\mathrm{N}$ (TN), and total P (TP) content. Another subsample was stored at $4{ }^{\circ} \mathrm{C}$ to measure soil microbial biomass $\mathrm{C}$ (SMBC), soil microbial biomass $\mathrm{N}$ (SMBN), and soil microbial biomass $\mathrm{P}$ (SMBP). The third subsample was stored at $-80{ }^{\circ} \mathrm{C}$ to determine enzymatic activity. 


\subsection{Biogeochemical analyses}

The chemical and physical properties of the soil were determined using standard procedures. SOC, TN, and TP content was measured following standard methods fully described by Zhang et al. (2019). Soil microbial biomass was measured by chloroform fumigation. Methodological details for measuring SMBC, SMBN, and SMBP are described by Zhang et al. (2019).

\subsection{Analyses of enzymatic activity}

The activities of $\beta$-1,4-glucosidase (BG), $\beta-1,4-\mathrm{N}$-acetylglucosaminidase (NAG), and alkaline phosphatase (AP) are commonly measured as indicators of energy (C) demand, $\mathrm{N}$ demand, and $\mathrm{P}$ demand, respectively (Schimel and Weintraub, 2003). The activities of these three ecoenzymes were measured as described by Saiya-Cork et al. (2002), with modifications based on German et al. (2011), which are also described in our previous study (Zhang et al., 2019).

\subsection{Statistical analyses}

All data were analyzed by one-way ANOVAs. Duncan's tests at $P<0.05$ were used for multiple comparisons. All statistical analyses and regressions were performed using SPSS 20.0. Differences were considered significant at $P<0.05$. Graphs were plotted using Origin 9.0.

TER for C:N and C:P (Allen and Gillooly, 2009) was calculated as:

$T E R_{C: N}=\left(\frac{A_{N}}{G E}\right) B_{C: N}$

$T E R_{C: P}=\left(\frac{A_{P}}{G E}\right) B_{C: P}$

where $A_{P}$ and $A_{N}$ are the assimilation efficiencies for $\mathrm{P}$ and $\mathrm{N}$, using 0.9 for both $A_{P}$ and $A_{N}$, GE (microbial growth efficiency) was set as 0.29 (Sinsabaugh et al., 2009), and $\mathrm{B}_{\mathrm{C}: \mathrm{N}}$ and $\mathrm{B}_{\mathrm{C}: \mathrm{P}}$ are the C:N and C:P ratios of microbial biomass.

The degree of community-level microbial C:N and C:P homeostasis (H) by soil microorganisms is represented as:

$\mathrm{H}=\frac{\log _{10}(x)}{\log _{10}(y)-\log _{10}(c)}$

where $\times$ is the resource nutrient stoichiometry (e.g., C:N or C:P), $y$ is the microbial nutrient stoichiometry, and $\mathrm{c}$ is a constant. Therefore, $1 / \mathrm{H}$ is the slope of the regression between $\log (\mathrm{y})$ and $\log (\mathrm{x})$ and should be between 0 and 1 . $\mathrm{H} \gg 1$ represents a strictly stoichiometric homeostasis, and $\mathrm{H} \approx 1$ indicates weak or no homeostasis (Sterner and Elser, 2002). Thus, the regression slope, $1 / \mathrm{H}$, could be used in this analysis. Data with significant regressions and $0<1 / \mathrm{H}<1$ were classified as homeostatic $(0<1 / \mathrm{H}<0.25)$, weakly homeostatic $(0.25<1$ ) $\mathrm{H}<0.5)$, weakly plastic $(0.5<1 / \mathrm{H}<0.75)$, or plastic (1/ $\mathrm{H}>0.75)$. We classified cases as strictly homeostatic if the least squared regression slope was not significant $(P>0.05)$.

\section{Results}

\subsection{Content and ratios of SOC, TN, and TP in the soils and TERs}

SOC and TN content was higher in the $0-20 \mathrm{~cm}$ compared to the 20-40 cm layer (Fig. 1). In addition, soil C:P and soil N:P were generally higher in the $0-20 \mathrm{~cm}$ compared to the $20-40 \mathrm{~cm}$ layer. TER $\mathrm{C}: \mathrm{N}_{\mathrm{N}}$ and $\mathrm{TER}_{\mathrm{C}: \mathrm{P}}$ in the $0-20 \mathrm{~cm}$ layer were 7.77 and 44.37 , respectively.

SOC, TN, and TP content in the 0-20 cm layer varied among these forest management practices, with SL always having the highest numerical value although the differences were not always significant. However, SOC, TN, and TP had numerically minimum values at different treatments, for GL, SPL and CK (Fig. 1), respectively. In the 20-40 cm layer, different forest management practices did not significantly change SOC contents, but did significantly change TN content. TN had the maximum numerical value for GL, which, however, had no significant difference with SL. TP content in the $20-40 \mathrm{~cm}$ layer was significantly decreased by LRL, while the TP content did not differ significantly among other practices (Fig. 1E).

In 0-20 cm, SOC:TN (soil C:N) and SOC:TP (soil C:P) had maximum numerical value for SL (16.50) and CK (83.78), respectively, and both had minimum numerical values at GL. TN:TP (soil N:P) showed no significant difference among the these practices (Fig. 1F) in the $0-20 \mathrm{~cm}$ soil layer. In addition, these forest management practices did not significantly change soil C:N and C:P in the $20-40 \mathrm{~cm}$. In the $20-40 \mathrm{~cm}$ layer, soil N:P was significantly higher in GL compared to the other practices.

\subsection{Content and ratios of $C, N$, and $P$ in soil microbial biomass}

These forest management practices significantly changed soil microbial biomasses both in $0-20 \mathrm{~cm}$ and $20-40 \mathrm{~cm}$ layer. Most microbial nutrients were generally higher in the $0-20 \mathrm{~cm}$ layer compared to the same practice in the $20-40 \mathrm{~cm}$ layer but not always significant (Table 1). MBC, MBN, and MBP in the $0-20 \mathrm{~cm}$ layer had the extreme values for the same practices, with highest values for SL, and minimum numerical values for LRL. Moreover, MBC, MBN, and MBP had the numerically maximum values for SL in the $20-40 \mathrm{~cm}$ layer. And MBN and MBP for SL was higher than other treatments in the 20-40 cm layer.

The numerically maximum values of MBC:N, MBC:P, and MBN:P varied among different practices (Table 1 ) in 0-20 cm layer. The MBC:N ratio in the $0-20 \mathrm{~cm}$ layer generally had maximum numerical value for SPL (3.16), and did not differ significantly with SL. In the $0-20 \mathrm{~cm}$ layer, MBC:P had numerically maximum value for SL (Table 1 ). The minimum numerical values for MBC:N and MBC:P were in GL, and for MBN:P it was in SPL. MBC:P and MBN:P in the $20-40 \mathrm{~cm}$ layer were highest for LRL, while SPL significantly increased MBC:N compared with other practices.

\subsection{Ecoenzymatic stoichiometry}

The forest management practice, SL, significantly increased BG, NAG, and AP activities compared with other practices in the $0-20 \mathrm{~cm}$ soil layer (Fig. 2). However, the rest of practices did not significantly change the ecoenzymatic activities. In the $20-40 \mathrm{~cm}$ layer, BG was highest for GL compared to the other practices, but showed no significant difference among the other practices. NAG showed no significant difference among the five practices. AP was significantly higher for GL and SL compared to CK, LRL, and SPL. In the 0-20 cm layer, BG:NAG had highest value in SL and numerically minimum value in LRL . NAG:AP was highest in LRL and had minimum numerical value in SL. BG:AP did not differ significantly among the treatments in the 0-20 cm soil layer. In the $20-40 \mathrm{~cm}$ layer, BG:NAG was highest in GL, and BG:AP had maximum numerical value in GL. NAG:AP did not differ significantly in the $20-40 \mathrm{~cm}$ layer.

We analyzed the energy-acquisition activities relative to the nutrient-acquisition activities for all treatments. The regressions indicated that $\ln (\mathrm{BG})$ vs $\ln (\mathrm{NAG})$ and $\ln (\mathrm{BG})$ vs $\ln (\mathrm{AP})$ for both soil layers were significantly linearly correlated (Fig. 3). The slopes of the regression lines for $\ln (\mathrm{BG}): \ln (\mathrm{NAG})$ for the $0-20$ and $20-40 \mathrm{~cm}$ layers were 0.9438 and 0.9189 , respectively, which were similar to previous reports of 0.96 and 0.889 (Waring et al., 2014). The slopes of the regression lines for $\ln$ (BG): $\ln (\mathrm{AP})$ for the $0-20$ and $20-40 \mathrm{~cm}$ layers were 0.9104 and 1.0629 , respectively, which were similar to previous reports of 0.9217 (Zhang et al., 2019) and 1.18 (Waring et al., 2014). All slopes were close to 1. 

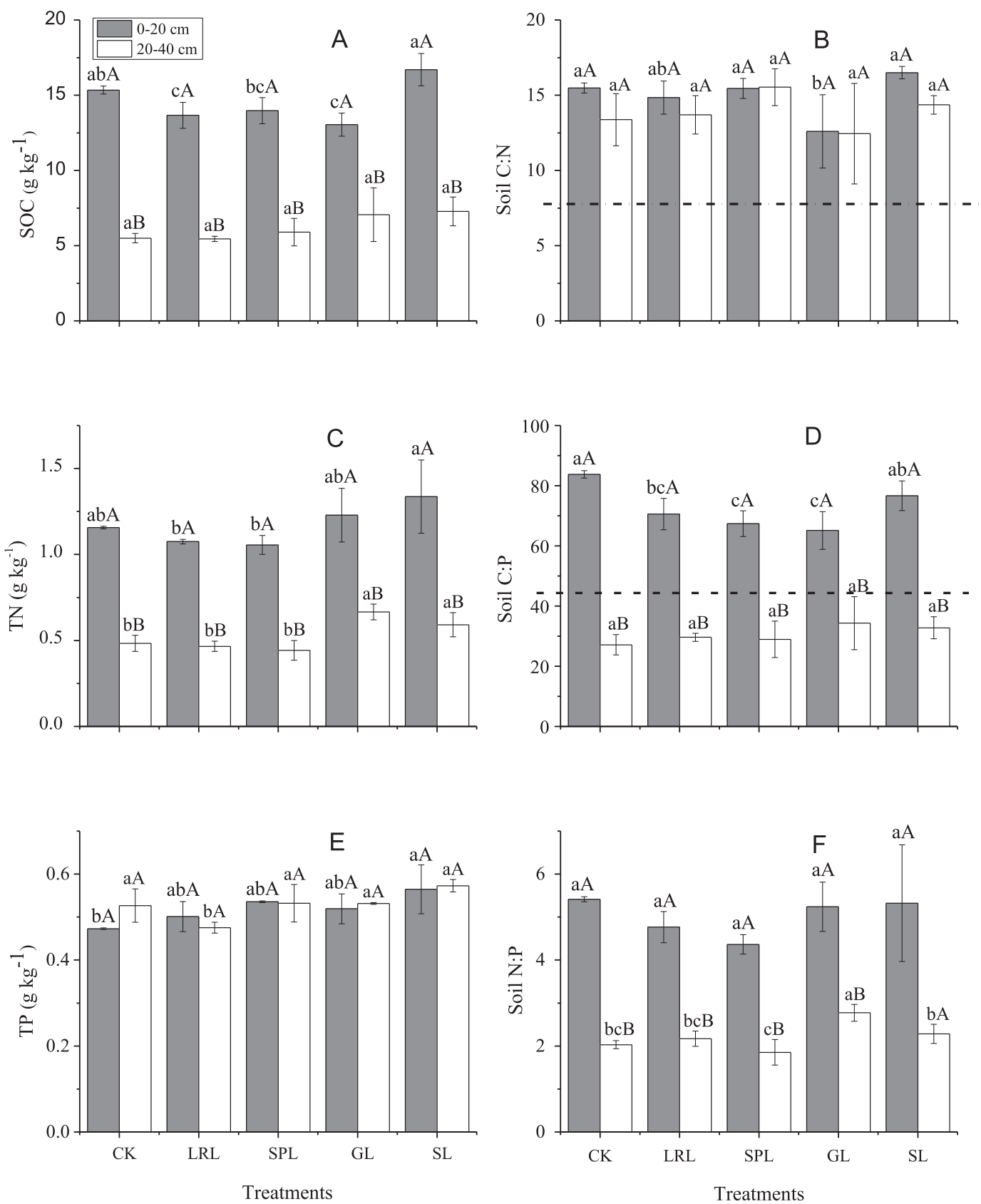

Fig. 1. The contents and ratios of SOC, TN and TP in the $0-20$ and $20-40 \mathrm{~cm}$ layers under different forest managements, CK, LRL, SPL, GL, and SL. Different lowercase letters represent significant differences among the different treatments in the same layer, the uppercase letters represent significant between different layers $(P<0.05)$. Error bars represent standard errors. The dot dash line in B represents TER $\mathrm{C}_{\mathrm{C} \cdot \mathrm{N}}$ for the $0-20 \mathrm{~cm}$ layer, and the dash line in $\mathrm{D}$ represents TER $\mathrm{C}_{\mathrm{P} P \mathrm{P}}$ for the $0-20 \mathrm{~cm}$ layer.

\subsection{Stoichiometric homeostasis}

We determined the associations between the microbial biomass elemental ratios and those for the soil resources to test the strength of stoichiometric homeostasis (Fig. 4). When all of the data for each layer were analyzed together, the slopes of $\log \left(\mathrm{C}: \mathrm{N}_{\mathrm{B}}\right)$ vs $\log \left(\mathrm{C}: \mathrm{N}_{\mathrm{R}}\right)$ in the $0-20$ and $20-40 \mathrm{~cm}$ layers were 0.5576 and 0.4947 , respectively, indicating weakly plastic and weakly homeostatic relationships. The correlation between $\log \left(\mathrm{C}: \mathrm{P}_{\mathrm{B}}\right)$ and $\log \left(\mathrm{C}: \mathrm{P}_{\mathrm{R}}\right)$ in the $0-20 \mathrm{~cm}$ and $20-40 \mathrm{~cm}$ layers was 0.3337 and -0.1371 , respectively, indicating a weakly homeostatic and homeoststic relationships between microbial C:P and soil C:P.

\section{Discussion}

Soil carbon and nutrient concentrations, microbial biomass, and microbial activity in the $20-40 \mathrm{~cm}$ layer had a similar trend with those in the $0-20 \mathrm{~cm}$ layer for the five forest management practices. Because of litter and surface roots, SOC and TN content was higher in the 0-20 cm layer compared to the same treatment the $20-40 \mathrm{~cm}$ layer. This might be the reason that some parameters were higher in the 0-20 cm layer compared to the $20-40 \mathrm{~cm}$ layer, and some parameters in the $20-40 \mathrm{~cm}$ showed no significant difference. Thus, we focused on the responses of elemental cycling and ecoenzymatic activity of microbes to forest management practices in the $0-20 \mathrm{~cm}$ layer. 
Table 1

Average MBC, MBN and MBP and ratios of MBC, MBN and MBP in the 0-20 and 20-40 cm layers.

\begin{tabular}{|c|c|c|c|c|c|c|c|}
\hline & Treatment & MBC & MBN & MBP & MBC:N & MBC:P & MBN:P \\
\hline \multirow[t]{5}{*}{$0-20 \mathrm{~cm}$} & CK & $86.19 \pm 8.30 \mathrm{bcA}$ & $40.09 \pm 2.69 \mathrm{bA}$ & $16.34 \pm 1.73 \mathrm{bcA}$ & $2.50 \pm 0.08 \mathrm{~cd}$ & $13.64 \pm 0.14 \mathrm{ab}$ & $5.45 \pm 0.23 a$ \\
\hline & LRL & $72.48 \pm 16.41 \mathrm{cA}$ & $30.33 \pm 5.94 \mathrm{cA}$ & $14.15 \pm 2.22 \mathrm{cA}$ & $2.78 \pm 0.09 \mathrm{bc}$ & $13.15 \pm 1.29 \mathrm{~b}$ & $4.73 \pm 0.36 \mathrm{ab}$ \\
\hline & SPL & $107.48 \pm 8.98 \mathrm{bA}$ & $39.69 \pm 1.96 \mathrm{bA}$ & $20.65 \pm 0.76 \mathrm{bA}$ & $3.16 \pm 0.12 \mathrm{a}$ & $13.44 \pm 0.74 \mathrm{ab}$ & $4.26 \pm 0.07 b$ \\
\hline & GL & $85.86 \pm 8.51 \mathrm{bcA}$ & $42.23 \pm 4.77 \mathrm{bA}$ & $17.13 \pm 1.55 \mathrm{bcA}$ & $2.39 \pm 0.36 \mathrm{~d}$ & $12.95 \pm 0.46 b$ & $5.48 \pm 0.07 a$ \\
\hline & SL & $160.41 \pm 27.04 \mathrm{aA}$ & $63.36 \pm 7.43 \mathrm{aA}$ & $28.34 \pm 5.50 \mathrm{aA}$ & $2.94 \pm 0.18 \mathrm{ab}$ & $14.69 \pm 0.65 a$ & $5.01 \pm 0.54 \mathrm{ab}$ \\
\hline \multirow[t]{5}{*}{$20-40 \mathrm{~cm}$} & CK & $53.66 \pm 8.40 \mathrm{cA}$ & $25.99 \pm 0.95 \mathrm{bcB}$ & $7.54 \pm 0.45 \mathrm{cB}$ & $2.40 \pm 0.30 \mathrm{~b}$ & $18.34 \pm 2.31 b$ & $7.63 \pm 0.02 b$ \\
\hline & LRL & $55.97 \pm 2.85 \mathrm{bcA}$ & $29.82 \pm 2.54 \mathrm{bA}$ & $4.97 \pm 0.66 \mathrm{~dB}$ & $2.19 \pm 0.08 \mathrm{~b}$ & $29.54 \pm 5.32 \mathrm{a}$ & $13.53 \pm 2.90 \mathrm{a}$ \\
\hline & SPL & $68.09 \pm 6.23 \mathrm{abB}$ & $24.63 \pm 1.31 \mathrm{cB}$ & $8.94 \pm 0.45 \mathrm{bB}$ & $3.23 \pm 0.28 \mathrm{a}$ & $19.75 \pm 2.68 b$ & $6.11 \pm 0.46 b$ \\
\hline & GL & $55.82 \pm 8.94 \mathrm{bcB}$ & $28.47 \pm 1.20 \mathrm{bcA}$ & $7.73 \pm 0.56 \mathrm{cB}$ & $2.29 \pm 0.41 b$ & $18.76 \pm 3.54 b$ & $8.17 \pm 0.25 b$ \\
\hline & SL & $74.83 \pm 6.52 \mathrm{aB}$ & $37.01 \pm 3.65 \mathrm{aB}$ & $10.80 \pm 0.86 \mathrm{aB}$ & $2.36 \pm 0.03 b$ & $17.99 \pm 2.24 b$ & $7.62 \pm 0.98 b$ \\
\hline
\end{tabular}

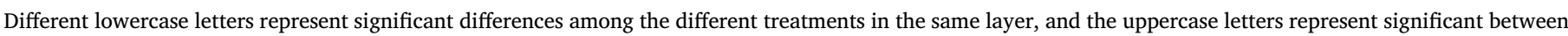
different layers $(P<0.05)$.

\subsection{Elements limitation for the soil microbial community after forest managements practices}

In the $0-20 \mathrm{~cm}$ layer, $\mathrm{TER}_{\mathrm{C}: \mathrm{N}}$ of 7.77 was calculated. Soil C:N in the 0-20 cm layer for all treatments was higher compared with calculated TER $_{C: N}$. Thus, all plots were $\mathrm{N}$-limited, which was supported by the lower BG:NAG obtained in the current study compared to previous study (BG:NAG $=1.41$ ) (Sinsabaugh et al., 2009). In the current study, soil $\mathrm{P}$ concentration increased in SL compared with $\mathrm{CK}$, and showed no significant difference among LRL, SPL, and GL in the $0-20 \mathrm{~cm}$ layer. Soil microbes in all treatments were $\mathrm{P}$ limited by comparing soil C:P with the calculated TER $\mathrm{C}_{\mathrm{P} P}$ of 42.33 , which was supported by the lower BG:AP obtained in the current study compared to previous studies (BG:AP = 0.62) (Sinsabaugh et al., 2009). This is also consistent with our previous study (Zhang et al., 2019). Most tropical forests are Plimited, while most arid forests are N-limited; however, recent studies showed that many arid forests are also be P-limited (DeForest et al., 2012).

However, the pattern of soil C:N and C:P changed with the C:N and C:P values for GL being significantly lower than CK, suggesting the limitation on $\mathrm{N}$ and $\mathrm{P}$ is reduced for the grassland treatment. These lower values were consistent with the significantly lower SOC value but numerically higher TN and TP values for GL compared to CK. This changed soil condition was not reflected in soil microbial biomass, however, as the highest soil microbial biomass was recorded in shrubland, not grassland. However, there were conditions where differences of soil microbial biomasses among different treatments were observed, like MBC for SL higher than CK, while no significant difference of SOC and TN for SL and CK. The reason may be that multiple factors had an effect on soil microbial biomass, e.g. SOC, TN, TP, and elemental ratios, and one should consider a combination of soil properties. In addition, soil properties, soil microbes and plant could have thresholds at different treatments (Zhang et al., 2017; Zhong et al., 2015), which may also be part of the reasons. In term of stoichiometry, some treatments with higher soil nutrient content still exhibited elemental limitation for microbial growth, possibly distributing more soil resources to ecoenzymes. This action is needed, rather than lowering soil nutrients content. Thus, microbial activity varies to adjust to different nutrient content among treatments.

\subsection{Ecoenzymes and elemental flow after forest management practices}

Soil enzymatic activity could be sensitive to both natural and human-induced disturbances. Consequently, measuring the activities of a range of ecoenzymes could provide a valid estimation of the metabolic responses of soils to forest management practices and environmental stress (Tan et al., 2008; Dick et al., 1988). In other words, the adaptation of microbes to resource stoichiometry is likely modified by different forest management practices. Microbes vary how they allocate resources to $\mathrm{C}-, \mathrm{N}$ - or $\mathrm{P}$-acquiring ecoenzymes depending on the relative demand for these resources for microbial growth (Allison et al., 2011). Thus, ecoenzyme activities should vary with different practices, as has been reported (Li et al., 2014; Acosta-Martinez et al., 2008), which was consistent with our results. In comparison, litter-removal treatment showed no significant difference, which was not expected, but was consistent with results from study conducted by Veres et al. (2015) that BG activity between CK and no litter treatment in most experiment years. However, Lie et al. (2016) showed that ecoenzyme activity was significantly lower in litter-removal plots compared to the control. This difference in enzymatic activity among land use types, but lack of significant difference with litter-removal, is because microbial ecoenzymatic activity is more strongly regulated by land use type than nutrient addition (Mganga et al., 2015). In addition, compared with our previous experiment conducted in a $P$. tabuliformis plantation, enzymatic activity also showed no significant difference. This result might be attributed to the secretion of $P$. tabuliformis to soil. Enzymatic activity is regulated by environmental and resource signals, in addition to environmental interactions after ecoenzymes are released from cells, such as edaphic and climatic variables (e.g., mean annual temperature and mean annual precipitation) (Sinsabaugh and Shah, 2012).

Energy-acquisition (C) activity relative to nutrient-acquisition (N, P) activity is 1:1:1 globally, indicating coupling in $\mathrm{C}, \mathrm{N}$, and $\mathrm{P}$ cycling. The soil energy-acquisition activity recorded in the current study was $<2$, and the soil nutrient-acquisition activity reported in the current study (Fig. 4) was $<5$. These values are among some of the lowest reported (Tapia-Torres et al., 2015), demonstrating the relatively oligotrophic nature of the soil. Sinsabaugh and Shah (2011) showed that in this model, resources directed toward producing ecoenzymes that increase the acquisition of a scarce nutrient are diverted from ecoenzyme expression pathways for higher availability. The soil enzymatic activity recorded in the current study was relatively low; however, the activity of ecoenzymes that acquire organic $\mathrm{N}$ and organic $\mathrm{P}$ were similar with our previous study (Zhang et al., 2019), and both scaled well with the activity of ecoenzymes that acquire C, with a slope of about 1 (Fig. 3). Thus, soil microbial communities exhibit similar patterns of allocation to nutrient acquisition, despite the structure of the microbial community being diverse due to the conditions caused by restoration activity following clear cutting and litter removal. These might be because if the resource supply remains stable, community composition is expected to reach state where $\mathrm{C}, \mathrm{N}$ and $\mathrm{P}$ are co-limiting (Danger et al., 2008).

SMBC, SMBN, and SMBP were highest in the 0-20 $\mathrm{cm}$ layer of shrubland, which might be caused by the roots and root exudates (Eilers et al., 2010). SMBC:N and SMBC:P were lower than soil C:N and C:P; thus, showing that $\mathrm{N}$ and $\mathrm{P}$ were further concentrated in soil microbial biomass (Sinsabaugh et al., 2009), which was supported by Cleveland and Liptzin (2007). In addition, ecoenzymatic activities was affected by elemental limitation. BG:NAG and NAG:AP activity ratios in the 0-20 cm showed opposite trends. Furthermore, the BG:NAG and BG:AP ratio in the $20-40 \mathrm{~cm}$ layer was significantly higher in GL compared to the other treatments, which was consistent with the trend for BG in the 

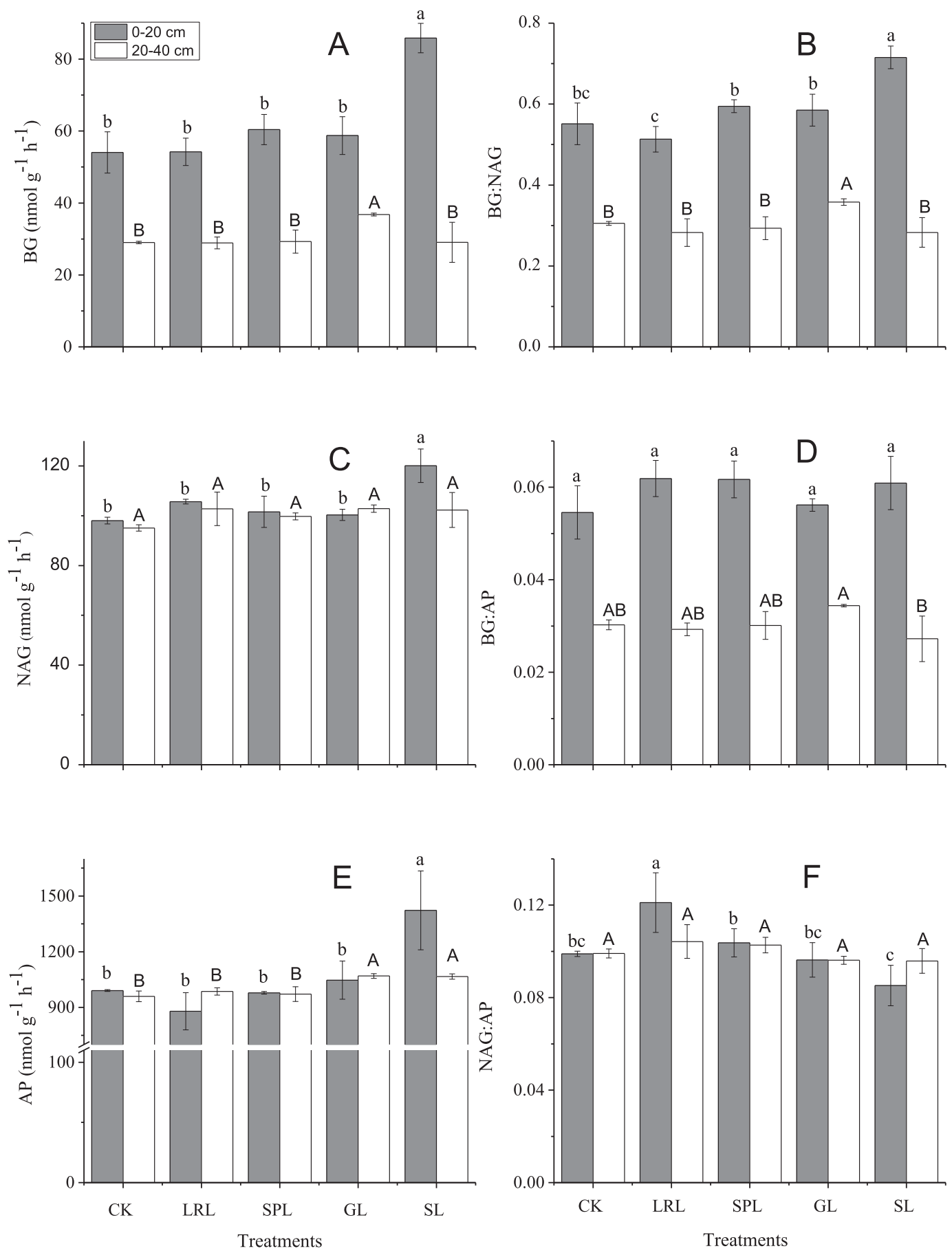

Fig. 2. Enzymatic activities and BG:NAG, BG:AP and NAG:AP activity ratios in the $0-20$ and $20-40 \mathrm{~cm}$ layers under different forest managements, CK, LRL, SPL, GL, and SL. Different letters represent significant differences of means for each layer $(P<0.05)$. Error bars represent standard errors.

$20-40 \mathrm{~cm}$ layer. In the current study, BG:NAG was about 0.6 and 0.3 in the $0-20$ and $20-40 \mathrm{~cm}$ layer, respectively, which is lower than the global level (1.41) (Sinsabaugh et al., 2009). Thus, the sample plots were N-limited. Overall, global soil NAG:AP was 0.44 , while soil BG:AP was 0.62 . These values were obtained from parts of typical plots that do not necessarily represent all forests (Sinsabaugh et al., 2009). Therefore, several studies have reported ratios that are inconsistent with global patterns (Waring et al., 2014). BG:AP in the 0-20 and 20-40 cm layers were about 0.06 and 0.03 , respectively. These values were much lower than 0.62 (Sinsabaugh et al., 2009), but were similar to 0.072 (Pamer et al., 2011). Thus, these forests are both N- and P-limited, similar results led by TER.

\subsection{Stoichiometric homeostasis of the soil microbial community after forest management practices}

The soils of the Loess Plateau in China are nutrient poor and Nlimited (Wang et al., 2004). Consequently, soil microbes have adjusted to the $P$. tabuliformis plantation without forest management practices. External changes, like forest management practices, could destabilize this relatively stable ecosystem. In this study, soil microbial communities were limited by $\mathrm{N}$ and co-limited by $\mathrm{P}$ in all treatments, which was supported by BG:NAG and BG:AP. The soil microbial community might adjust physiologically to cope with this limitation and attain a new balance with available resources. The $\log \left(C: N_{R}\right)$ and $\log \left(C: N_{B}\right)$ in 

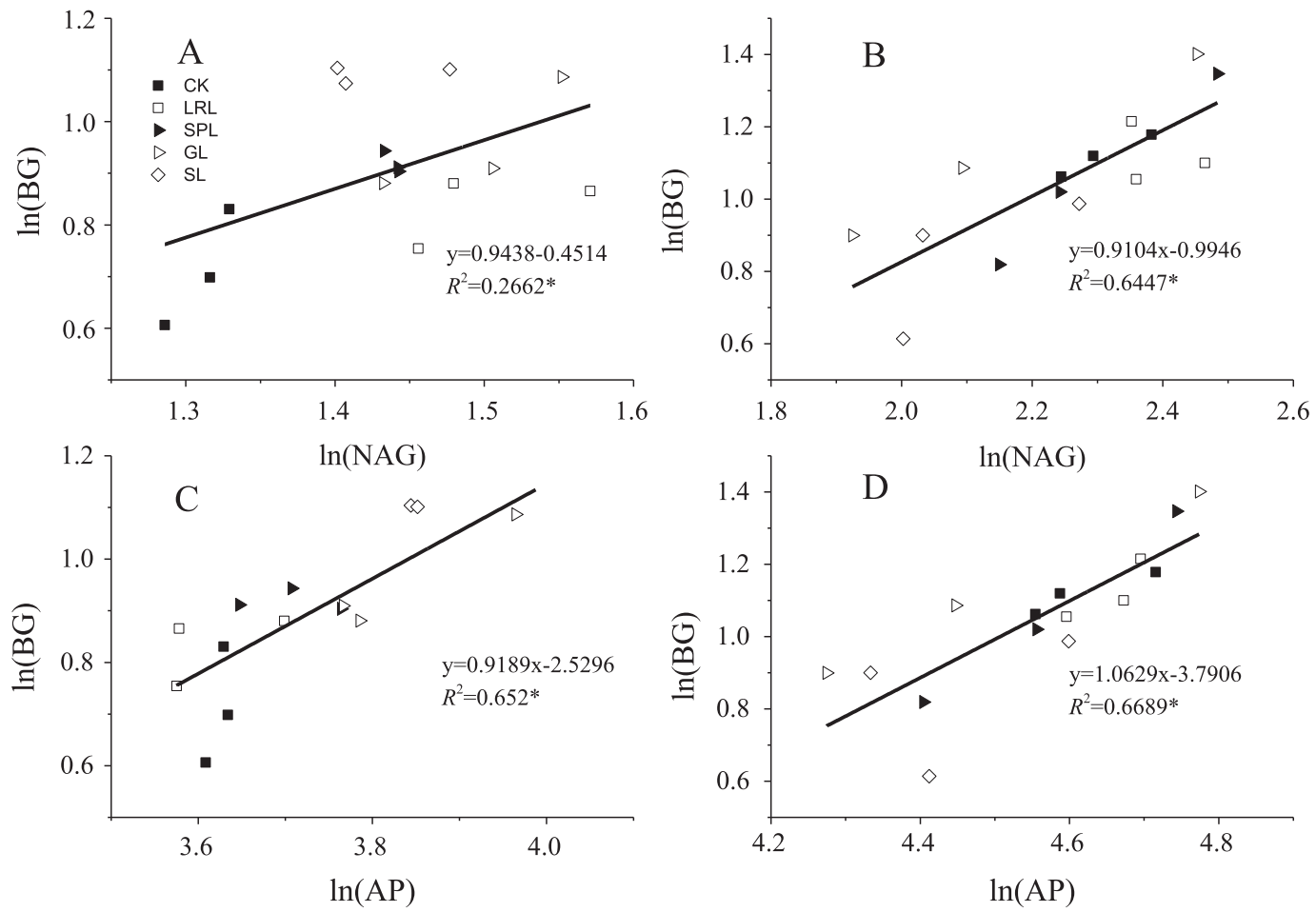

Fig. 3. Activities of enzymes for acquiring organic nitrogen $(\mathrm{N})$ and organic phosphorus $(\mathrm{P})$ relative to the activity of the enzyme for acquiring carbon $(\mathrm{C})$ in the $0-20$ and 20-40 cm layers. $\mathrm{N}$ acquisition is measured by the potential activity of $\beta-1,4-\mathrm{N}$-acetylglucosaminidase (NAG) (A, B), P acquisition is measured by the potential activity of alkaline phosphatase (AP) (C, D) and C acquisition is represented by the potential activity of $\beta$-1,4-glucosidase (BG). A and C indicate the relationship in the 0-20 cm layer and B and D indicate the relationship in the 20-40 cm layer. Significant correlations are indicated by asterisks $\left(^{*}\right)(P<0.05)$. Nutrient and energy acquisition are expressed as enzymatic activities in $\mathrm{nmol} \mathrm{h}^{-1} \mathrm{~g}^{-1}$ soil organic matter.
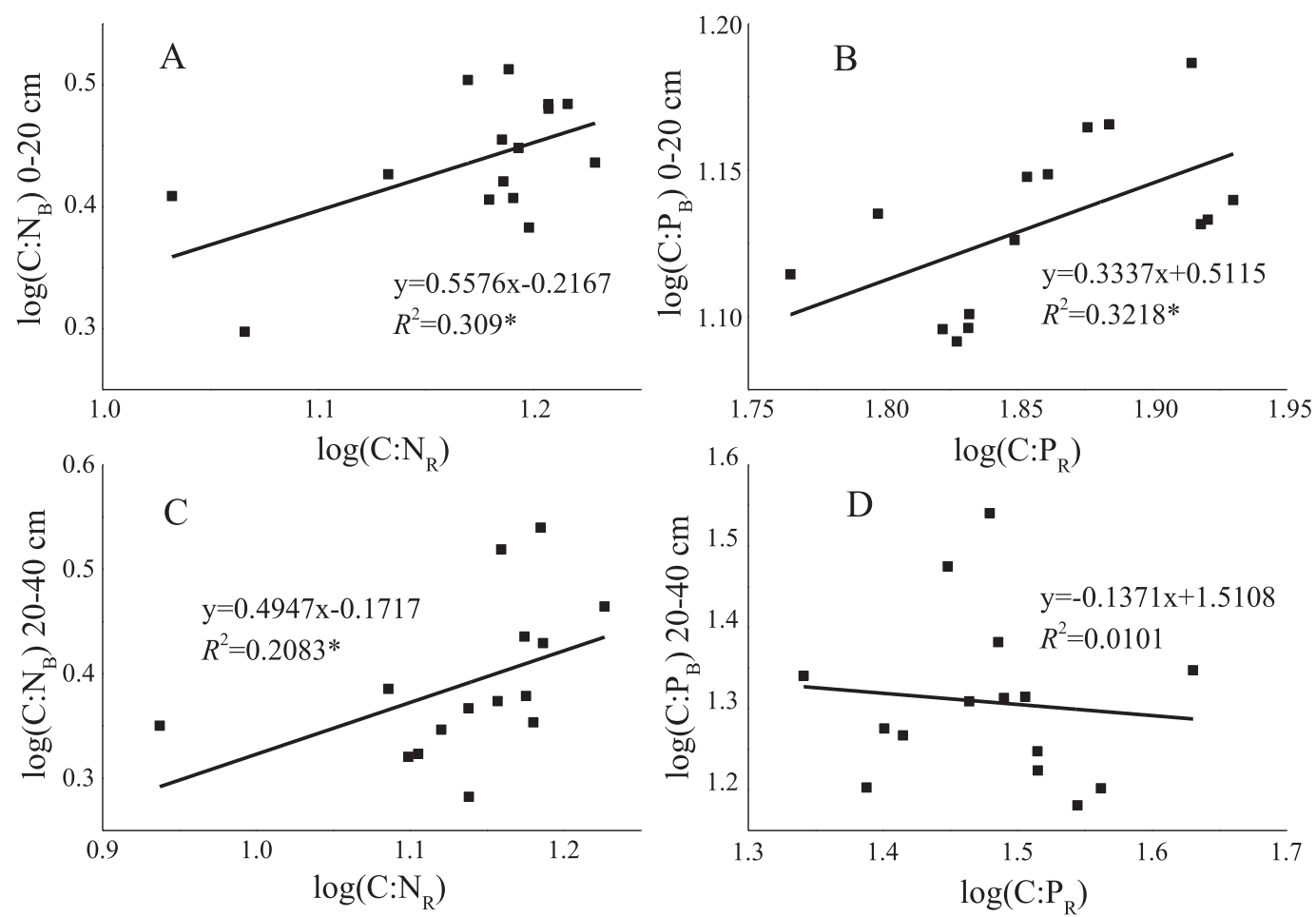

Fig. 4. Soil microbial community homeostasis correlated with $\mathrm{N}$ (left panels) and $\mathrm{P}$ (right panels) acquisition in the $0-20$ and $20-40 \mathrm{~cm}$ layers. The regression equation for each panel is: $\mathrm{A}: \mathrm{y}=-0.5576 \mathrm{x}-0.2167 R^{2}=0.309(P<0.05)$; $\mathrm{B}: \mathrm{y}=0.3337 \mathrm{x}+0.5115 R^{2}=0.3218(P<0.05)$; $\mathrm{C}: \mathrm{y}=0.4947 \mathrm{x}+0.1717$ $R^{2}=0.2083(P<0.05)$ and $\mathrm{D}: \mathrm{y}=-0.1371 \mathrm{x}+1.5108 R^{2}=0.0101$. 
the $0-20 \mathrm{~cm}$ layers generated slopes that were weakly plastic (0.5576), while the slopes in the $20-40 \mathrm{~cm}$ layer were weakly homeostatic (0.4947) (Fig. 4). Thus, microbial nutrients appeared to be dependent on soil resources (Fig. 4). According to principles, stoichiometries of autotrophic organisms are generally plastic, changing with resources stoichiometry (Sterner et al., 1998). The relationship between $\log \left(\mathrm{C}: \mathrm{N}_{\mathrm{R}}\right)$ and $\log \left(\mathrm{C}: \mathrm{N}_{\mathrm{B}}\right)$ showed that the microorganisms were autotrophic. The slopes of $\log \left(\mathrm{C}: \mathrm{P}_{\mathrm{R}}\right)$ and $\log \left(\mathrm{C}: \mathrm{P}_{\mathrm{B}}\right)$ for the $0-20 \mathrm{~cm}$ layers were between 0.25 and 0.5 , indicating weak homeostasis. $\log \left(\mathrm{C}: \mathrm{P}_{\mathrm{R}}\right)$ and $\log \left(\mathrm{C}: \mathrm{P}_{\mathrm{B}}\right)$ in the $20-40 \mathrm{~cm}$ layers had slopes that did not differ significantly from 0 (Fig. 4). According to principle, variation in resource stoichiometry has little effect on the elemental composition of heterotrophs generally thought to be strictly homeostatic (Fagan et al., 2002). Thus, microbial nutrients were independent of soil resources, and the microbes might be heterotrophic. However, P homeostasis for some heterotrophs might range from weak to strong homeostasis (DeMott and Pape, 2005), explaining the contrasting results obtained in our study. This discrepancy should be further studied to advance our understanding of the mechanisms driving it. In addition, the soil microbial community in the 0-20 cm layer was more strongly affected by management practices than the community in the $20-40 \mathrm{~cm}$. This phenomenon indicates the flexible status of the microbial community, which might be induced by changes to the biogeochemical cycle caused by forest management practices.

\section{Conclusions}

This study showed that the soil microbial communities of the artificial plantation are limited by $\mathrm{N}$ and $\mathrm{P}$, with none of the forest management practices alleviating the nutrient co-limitation status. Enzymatic activities and ecoenzymatic stoichiometries, BG:AP, generally remained unchanged. Ecoenzymatic stoichiometries, BG:NAG and NAG:AP, differed significantly among the five forest management practices. Furthermore, the activity of ecoenzymes for acquiring organic $\mathrm{N}$ and organic $\mathrm{P}$ scaled with ecoenzyme activity for acquiring $\mathrm{C}$, following the global pattern. Forest management practices did not interfere with soil microbial homeostasis. The soil background status on the Loess Plateau had a much stronger effect at shaping the soil microbial community than forest management practices. This study advances our understanding on the flow of energy and nutrients in the food web during the process of vegetation restoration after clear-cutting and litter-removal. Further study on the structure of soil microbial communities is needed to identify which groups of microbes respond to forest management practices, along with the microbes that are heterotrophic for maintaining homeostasis. Such information could provide insights on the involved mechanisms.

\section{Acknowledgments}

We thank the anonymous reviewers and the editors of the journal who provided constructive comments and suggestions on the manuscript. This work was supported by the Natural Science Foundation of China (41771557, 41671513) and National Key Research and Development Program of China (2016YFC0501707). Special thanks go to the China Scholarship Council (Grant No. 20184910482).

\section{Appendix A. Supplementary data}

Supplementary data to this article can be found online at https:// doi.org/10.1016/j.geoderma.2019.114108.

\section{References:}

Allison, S.D., Weintraub, M.N., Gartner, T.B., Waldrop, M.P., 2011. Evolutionary-economic principles as regulators of soil enzyme production and ecosystem function. In: Shukla, G.C., Varma, A. (Eds.), Soil Enzymology. Springer, Berlin, Heidelberg, pp.
$229-243$.

Acosta-Martinez, V., Acosta-Mercado, D., Sotomayor-Ramirez, D., Cruz-Rodriguez, L. 2008. Microbial communities and enzymatic activities under different management in semiarid soils. Appl. Soil Ecol. 38, 249-260.

Acosta-Martinez, V., Cruz, L., Sotomayor-Ramirez, D., Perez-Alegria, L., 2007. Enzyme activities as affected by soil properties and land use in a tropical watershed. Appl. Soil Ecol. 35, 35-45.

Allen, A.P., Gillooly, J.F., 2009. Towards an integration of ecological stoichiometry and the metabolic theory of ecology to better understand nutrient cycling. Ecol. Lett. 12, 369-384.

Bissett, A., Richardson, A.E., Baker, G., Thrall, P.H., 2011. Long-term land use effects on soil microbial community structure and function. Appl. Soil Ecol. 51, 66-78.

Cleveland, C.C., Liptzin, D., 2007. C : N : P stoichiometry in soil: is there a "redfield ratio" for the microbial biomass? Biogeochemistry 85, 235-252.

Danger, M., Daufresne, T., Lucas, F., Pissard, S., Lacroix, G., 2008. Does liebig's law of the minimum scale up from species to communities? Oikos 117 (11), 1741-1751.

DeForest, J.L., Smemo, K.A., Burke, D.J., Elliott, H.L., Becker, J.C., 2012. Soil microbial responses to elevated phosphorus and $\mathrm{pH}$ in acidic temperate deciduous forests. Biogeochemistry 109, 189-202.

DeMott, W.R., Pape, B.J., 2005. Stoichiometry in an ecological context: testing for links between Daphnia P-content, growth rate and habitat preference. Oecologia 142, 20-27.

Dick, R.P., Myrold, D.D., Kerle, E.A., 1988. Microbial biomass and soil enzyme-activities in compacted and rehabilitated skid trail soils. Soil Sci. Soc. Am. J. 52, 512-516.

Eilers, K.G., Lauber, C.L., Knight, R., Fierer, N., 2010. Shifts in bacterial community structure associated with inputs of low molecular weight carbon compounds to soil. Soil Biol. Biochem. 42, 896-903.

Fagan, W.F., Siemann, E., Mitter, C.M., Denno, R.F., Huberty, A.F., Woods, H.A., 2002. Nitrogen in insects: implications for trophic complexity and species diversification. Integr. Comp. Biol. 42, 1228.

Gao, Y., He, N.P., Yu, G.R., Chen, W.L., Wang, Q.F., 2014. Long-term effects of different land use types on $\mathrm{C}, \mathrm{N}$, and P stoichiometry and storage in subtropical ecosystems: a case study in China. Ecol. Eng. 67, 171-181.

German, D.P., Weintraub, M.N., Grandy, A.S., Lauber, C.L., Rinkes, Z.L., Allison, S.D. 2011. Optimization of hydrolytic and oxidative enzyme methods for ecosystem studies. Soil Biol. Biochem. 43, 1387-1397.

Goodale, C.L., Apps, M.J., Birdsey, R.A., Field, C.B., Heath, L.S., Houghton, R.A., Jenkins, J.C., Kohlmaier, G.H., Kurz, W., Liu, S.R., Nabuurs, G.J., Nilsson, S., Shvidenko, A.Z. 2002. Forest carbon sinks in the Northern Hemisphere. Ecol. Appl. 12, 891-899.

Huang, W.J., Spohn, M., 2015. Effects of long-term litter manipulation on soil carbon, nitrogen, and phosphorus in a temperate deciduous forest. Soil Biol. Biochem. 83, $12-18$.

Jobbagy, E.G., Jackson, R.B., 2000. The vertical distribution of soil organic carbon and its relation to climate and vegetation. Ecol. Appl. 10, 423-436.

Li, Q., Liang, J.H., He, Y.Y., Hu, Q.J., Yu, S., 2014. Effect of land use on soil enzyme activities at karst area in Nanchuan, Chongqing, Southwest China. Plant Soil Environ. $60,15-20$.

Li, Q.C., Allen, H.L., Wollum, A.G., 2004. Microbial biomass and bacterial functional diversity in forest soils: effects of organic matter removal, compaction, and vegetation control. Soil Biol. Biochem. 36, 571-579.

Lie, G.W., Xue, L., Zeng, S.C., 2016. Impact of litter removal on soil characteristics under a Pinus caribaea stand. Toxicol. Environ. Chem. 98, 571-584.

Luyssaert, S., Ciais, P., Piao, S.L., Schulze, E.D., Jung, M., Zaehle, S., Schelhaas, M.J., Reichstein, M., Churkina, G., Papale, D., Abril, G., Beer, C., Grace, J., Loustau, D., Matteucci, G., Magnani, F., Nabuurs, G.J., Verbeeck, H., Sulkava, M., van der Werf, G.R., Janssens, I.A., C.-I.S. Team, 2010. The European carbon balance. Part 3: forests. Glob. Change Biol. 16, 1429-1450.

Mganga, K.Z., Razavi, B.S., Kuzyakov, Y., 2015. Microbial and enzymes response to nutrient additions in soils of Mt. Kilimanjaro region depending on land use. Eur. J. Soil Biol. 69, 33-40.

Pamer, E., Vujovic, G., Knezevic, P., Kojic, D., Prvulovic, D., Miljanovic, B., Grubor-Lajsic, G., 2011. Water quality assessment in lakes of Vojvodina. Int. J. Environ. Res. 5, 891-900.

Raiesi, F., Beheshti, A., 2015. Microbiological indicators of soil quality and degradation following conversion of native forests to continuous croplands. Ecol. Ind. 50, 173-185.

Saiya-Cork, K.R., Sinsabaugh, R.L., Zak, D.R., 2002. The effects of long term nitrogen deposition on extracellular enzyme activity in an Acer saccharum forest soil. Soil Biol. Biochem. 34, 1309-1315.

Salazar, S., Sanchez, L.E., Alvarez, J., Valverde, A., Galindo, P., Igual, J.M., Peix, A. Santa-Regina, I., 2011. Correlation among soil enzyme activities under different forest system management practices. Ecol. Eng. 37, 1123-1131.

Sayer, E.J., 2006. Using experimental manipulation to assess the roles of leaf litter in the functioning of forest ecosystems. Biol. Rev. 81, 1-31.

Schimel, J.P., Weintraub, M.N., 2003. The implications of exoenzyme activity on microbial carbon and nitrogen limitation in soil: a theoretical model. Soil Biol. Biochem. 35, 549-563.

Sicardi, M., Garcia-Prechac, F., Frioni, L., 2004. Soil microbial indicators sensitive to land use conversion from pastures to commercial Eucalyptus grandis (Hill ex Maiden) plantations in Uruguay. Appl. Soil Ecol. 27, 125-133.

Sinsabaugh, R.L., Hill, B.H., Shah, J.J.F., 2009. Ecoenzymatic stoichiometry of microbial organic nutrient acquisition in soil and sediment. Nature 462, 795-U117.

Sinsabaugh, R.L., Shah, J., 2012. Ecoenzymatic Stoichiometry and Ecological Theory. In: Futuyma, D.J. (Ed.), Annual Review of Ecology Evolution and Systematics. Annual Reviews, Palo Alto, pp. 313-343.

Sinsabaugh, R.L., Shah, J., 2011. Ecoenzymatic stoichiometry of recalcitrant organic 
matter decomposition: the growth rate hypothesis in reverse. Biogeochemistry 102 (1-3), 31-43.

Six, J., Callewaert, P., Lenders, S., De Gryze, S., Morris, S.J., Gregorich, E.G., Paul, E.A., Paustian, K., 2002. Measuring and understanding carbon storage in afforested soils by physical fractionation. Soil Sci. Soc. Am. J. 66, 1981-1987.

Sterner, R.W., Clasen, J., Lampert, W., Weisse, T., 1998. Carbon: phosphorus stoichiometry and food chain production. Ecol. Lett. 1, 146-150.

Sterner, R.W., Elser, J.J., 2002. Ecological stoichiometry:the biology of elements from moleculaes to the biosphere. Princeton University Press, Princeton, New Jersey, USA.

Tan, X., Chang, S.X., Kabzems, R., 2008. Soil compaction and forest floor removal reduced microbial biomass and enzyme activities in a boreal aspen forest soil. Biol. Fertil. Soils 44, 471-479.

Tapia-Torres, Y., Elser, J.J., Souza, V., Garcia-Oliva, F., 2015. Ecoenzymatic stoichiometry at the extremes: how microbes cope in an ultra-oligotrophic desert soil. Soil Biol. Biochem. 87, 34-42.

Veres, Z., Kotroczo, Z., Fekete, I., Toth, J.A., Lajtha, K., Townsend, K., Tothmeresz, B., 2015. Soil extracellular enzyme activities are sensitive indicators of detrital inputs and carbon availability. Appl. Soil Ecol. 92, 18-23.

Wang, L., Li, Y.Y., Li, Y.Y., 2004. The eco-environment deterioration and its countermeasures in the Loess Plateau. J. Nat. Res. 19, 263-271.

Waring, B.G., Weintraub, S.R., Sinsabaugh, R.L., 2014. Ecoenzymatic stoichiometry of microbial nutrient acquisition in tropical soils. Biogeochemistry 117, 101-113.

Zhang, J., Ai, Z., Liang, C., Wang, G., Xue, S., 2017. Response of soil microbial communities and nitrogen thresholds of Bothriochloa ischaemum to short-term nitrogen addition on the Loess Plateau. Geoderma 308, 112-119.

Zhang, J.Y., Ai, Z.M., Liang, C.T., Wang, G.L., Liu, G.B., Xue, S., 2019. How microbes cope with short-term $\mathrm{N}$ addition in a Pinus tabuliformis forest-ecological stoichiometry. Geoderma 337, 630-640.

Zhao, Q., Classen, A.T., Wang, W.W., Zhao, X.R., Mao, B., Zeng, D.H., 2017. Asymmetric effects of litter removal and litter addition on the structure and function of soil microbial communities in a managed pine forest. Plant Soil 414, 81-93.

Zhong, Y., Yan, W., Zhouping, S., 2015. Impact of long-term N additions upon coupling between soil microbial community structure and activity, and nutrient-use efficiencies. Soil Biol. Biochem. 91, 151-159. 